\title{
Immigrants' Paths to Employment in Finland
}

\author{
AINI PEHKONEN, D.Soc.Sc \\ Lecturer of Social Work, \\ Department of Social Work and Social Pedagogy, \\ University of Kuopio
}

\section{Abstract}

The aim of this study was to investigate how immigrants have integrated into Finnish life from the standpoints of employment. The empirical research material consisted of 30 interviews with immigrants and four interviews with officials and others dealing with immigrant affairs.

Factors promoting employment of immigrants were the voluntary nature of the immigration, educational qualifications as demonstrated by the relevant certificates and knowledge of the Finnish language. One in three reported that they had first received information about vacancies from the Employment Office, and one in five by approaching the employer directly asking for work. One in seven had found out about jobs through friends.

Keywords: immigration, integration, employment, social capital

\section{Introduction}

Finland has gradually turned from being an exporter of labour into a country receiving immigrants. The direction of migration only changed as recently as the beginning of the 1980s, when the number of immigrants exceeded the number of emigrants for the first time. Over the decades, immigration has aroused considerable debate in Finland, especially during the early 1990 s when the rise in immigration coincided with a difficult period of economic recession. Because of this recession, large numbers of immigrants became long-term unemployed (Maahanmuuttajien elinolot 2003, 10-11.) At the end of 2004, there were 108,346 foreigners permanently resident in Finland, about $2 \%$ of the population. In Finland, immigrants have mainly settled in the largest towns and cities and very often in certain districts. In 2003 immigrants made up 5.3\% of the population of Helsinki, 4.2\% in Vantaa and 4.1\% in Espoo (Statistical Yearbook of Finland 2004, 153-154). Concentrations of immigrants can be observed elsewhere in the world, and the phenomenon of immigrants gathering in the neighbourhood of 
other members of their ethnic group is not new. However the immigrant population in Finland is still relatively scattered by comparison with most European countries, because immigrant communities are small.

Migration can be divided into free and refugee migration. Free migration can be either internal migration within a country or migration between countries. There are a variety of theories concerning the causes and effects of migration, some of which emphasise the attraction factors of recipient countries, others the migration pressures in countries of origin. According to neoclassical economic theoretical models, migration can be analysed as a process of labour supply and demand. In that case people would migrate in order to maximise the output of their human capital in terms of skills and work. Correspondingly, labour market theories stress that being a migrant is no temporary status of part of the population, but rather a division occurs in labour markets. Sociological theoretical models, by contrast, focus on the origin of the decision to migrate and its consequences, while world-systems theories study the movements of capital, goods and labour as intricately interwoven systems (Ylänkö 2000, 33; see also Stalker 2000).

On the global scale, streams of migration have diversified and politicised (Castles and Miller 1998), and so the migration directed towards Finland is part of a global process. Formerly, a certain country received a certain type of migrant, whether labour migrants or refugees. Nowadays, different types of immigrants are arriving at the same time, and one type has a tendency to mutate into another. After the settlement of refugees in a country, family reunification follows. For this reason, among others, the proportion of women migrants has increased. Castles and Miller (1998) use the term politicisation of migration, to refer to the way issues related to migration are caught up in national politics, international relations and national security issues. As a result the concepts of democracy, solidarity, freedom, welfare and human rights are increasingly the subject of international debate. The discussion of the ethical dimensions of globalisation is gradually opening up.

From a global perspective, standard of living discrepancies and political conflicts are the best explanations of worldwide migration streams (e.g. Ylänkö 2000, 23). In addition, it has been shown that immigration is substantially reduced when the standard of living of the country of origin is $60-70 \%$ of that of the country of destination (Stenberg 2004). On the one hand, an individual has the right to leave his or her country on human rights grounds, but on the other hand, there is no corresponding automatic right to be granted a residence permit by the second nation involved. The purpose of limiting immigration is not, however to prevent foreigners moving to a country or enjoying its advantages. Thomas Hammar (1990) has argued that the purpose of limits on immigration is to safeguard the principle of the equality of all the country's residents. 
The challenge for a modern welfare state is to find a way to guarantee all its residents the same standard of work, living and education, and prevent the emergence of a permanent underclass, and also acceptance of the existence of such a class. According to the Contact Hypothesis of Allport (1954), people are naturally prejudiced against foreigners and strangers, but as contacts increase between different groups, prejudices gradually wane. On the other hand the Conflict Theory of Lange and Westin (1981) takes as its starting-point the idea that as time goes by, prejudice and discrimination increase, as a consequence of the growth in numbers of immigrants and the resulting competition in different fields of life, for example competition for jobs.

In Finland, integration policy means the social measures taken to encourage immigrants to find an active role in Finnish society. The Acts on the Integration of Immigrants $(1999,2006)$ determine the content of Finnish immigration policy. Any immigrant who registers as a jobseeker or applies for income support has the right to an 'integration plan' to be drawn up in cooperation with the local authority and the local Employment Office, in which measures are agreed to support the immigrant and their family in the acquisition of the knowledge and skills required in Finnish society. The immigrant has the right to an 'integration plan' for three years following immigration. Local authorities have the overall responsibility for applying immigration policy. The Act has been revised this year 2006 to specify more precisely the roles of the various government departments and to extend the rights of immigrants to 'integration plans'.

Finland's most recent Aliens' Act came into force 1.5.2004. Its main aims are to uphold good administrative practice and legal protection in alien affairs and to promote controlled immigration and international security. The law pays closer attention than before to foreigners' rights, but also to foreigners' duties. The new Aliens' Act requires a foreigner to be continuously resident in Finland for four years before becoming eligible for a permanent Finnish residence permit. In EU directives, the required residence period is five years. Parliament has called for the functioning of the new Aliens' Act to be closely monitored, with special attention paid to issues affecting the status and rights of children, the status of foreign students and the overall handling of foreigners' affairs, in order to enable any necessary revisions of the law to be carried out as rapidly as possible.

How immigrants relate to the majority population, immigrant communities and their own ethnic group, and also how the majority population relates to immigrants, are all closely bound together. Macro-level, meso-level and micro-level relationships determine the social position of immigrants in society. If immigrants are sidelined from the power structures of society (work, education, political and social participation), or their role is only marginal, recognition of cultural pluralism will probably be made more difficult (Ekholm 1994, 41). In addition, integration into one's own ethnic group 
has been considered to be a factor opening the way to integration into the majority society. Members of ethnic groups may have very different interests and even opposing aims, so that immigrants do not automatically make up a solid community. At its best, and not only among immigrants, group consciousness can generate a sense of community, social support and possibly institutional structures (e.g. Rath 2000, 5-6; Forsander 2001, 40-41; Pehkonen 2005).

\section{Social capital}

Social capital is linked with social integration. Social capital (Bourdieu 1979; 1986; Coleman 1988; Putnam 1993; 2000) includes the idea that confidence in society, official and unofficial modes of operation of communities, citizens' interaction networks, values, social norms and other social structures all have a vital effect on economic development and intensify the realisation of individual goals. It can be argued that social capital increases the well-being of individuals and communities, because trustful social networks and social support facilitate people's activities. When people are involved together and trust each other, social interaction is made easier and the flow of information is improved. The main areas of social capital are: trust, social networks and participation, although social capital does not always work to the advantage of social networks.

James Coleman (1988) distinguishes different forms of social capital, including the duty of reciprocity, information channels and social norms. The duty of reciprocity is fulfilled when in helping others, one can be confident of receiving help oneself in the future. In Coleman's concept of social capital, the social networks are so dense that the possibility of a conflict between the community's and the individual's goals is ignored. Robert Putnam (1995) linked the concept of social capital with broad social contexts. For him parallel concepts include active citizenship and civic virtues, and also social and community infrastructure. Putnam holds that social capital facilitates the coordination and cooperation of different groups and interests.

Pierre Bourdieu (1979) uses the term 'social capital' to refer to one dimension of the class status of human beings. In Bourdieu's thinking, class status is defined by the control of three types of capital: financial capital (stocks, land, possessions), cultural capital (acquired cultural skills, knowledge and qualifications), and social capital. Besides these, there also exists a symbolic form of capital given to each of these when they are processed using certain perceptual categories which truly recognise their intrinsic logic.

Social capital presupposes cooperation between people acting together and creating the opportunity to bring wellbeing and positive economic effects at both the individual 
and the social or communal level. When social capital is analysed at the macro-level, attention can be paid to the flow of information, to understanding that flow, and further to the relationships between social identity groups or interest groups, and the ability of the state to arbitrate conflicts between these groups. At the meso-level, one of the most important aspects is the ability of a community to bring about and maintain trust in the interaction between its members. The tolerance of diversity in a community is also important, as that guarantees the preservation of community dynamics. At the micro-level, attention is paid to the available relationship networks, the trust in the network and "structural gaps". The latter is important, for example, for the recognition of barriers to the spread of information (Ruuskanen 2001, 49).

Trust and confidence have been held to occupy a central place in social capital, although distrust is also needed to test moral principles (Hyyppä 2002,148). Trust cannot be separated from its social connexions and is time-bound and place-bound. Piotr Sztompka (1999, 103-106; Ilmonen 2002, 95-101) defines the central task of trust as to increase activism and mobilisation at both individual and community levels. Trust liberates us to find new creative solutions. What is more, trust increases resources, because the more people an individual trusts, the more opportunities open up to gain information and social support for actions. Trust increases the flow of information, binds the individual to his/her community, increases tolerance and creates and maintains a sense of security.

Social capital is difficult to measure. It is a challenge to devise quantitative indicators for social capital, as also for human capital. Putnam (2000), Coleman (1988), Spellerberg (1997) and Green et al. (2000) are among those who have developed social capital indicators. The indicators proposed by Putnam are based on elements that describe the social capital of local communities, such as the organisation of the community, the engagement of citizens in communal matters, the voluntary work done in the community, unofficial socialising and social trust (Simpura 2002, 207). Coleman's indicators for measuring social capital are the size of family, mothers' expectations of bringing up children, the presence of parents in the home, family relocations and church activities. The basic idea of Anne Spellerberg's (1997) framework for the measurement of social capital is the parallel analysis of population data, information about attitudes and levels of participation. Geoff Green and others classify empowerment according to eight aspects: neighbourhood bonds, geographic networks, mutual assistance, trust, civic engagement, state of health, lifestyle and economic. The aim is to demonstrate the existence of common values and norms (Ruuskanen 2001; Simpura 2002).

Research in Finland relating to measuring social capital has been carried out by, among others, Hyyppä (2002), Ilmonen (2002), Niemelä (2004), Pulkkinen (2002) and Sinkkonen-Tolppi (2005). Markku T. Hyyppä in his study of the Swedish-speaking 
communities of the Ostrobothnian coast has shown the link between social capital and good health. Kaj Ilmonen has studied the manifestations of trust in local institutions and social networks. His study found that there is still considerable trust, but it is not without cracks. Finns still trust each other strongly, but less strongly than before. Lea Pulkkinen brings out the idea of initial social capital, which is built up in childhood and facilitates favourable development and the growth of adult social capital. Merja Sinkkonen-Tolppi (2005) shows in her study that of the dimensions of young people's social capital, school and family are related to attachment to one's local community.

Pauli Niemelä (2004) in his study of social capital in Finnish municipalities and rural districts found that social capital is manifested, among other things, as confidence in the functioning of democracy and good administration, as the fulfilment of municipal social responsibility and in civic participation. Social capital is measured using five different categories of indicator, containing altogether c. 30 indicators. The categories are social-political participation, and social networks, external community image, internal community image, security and social integration, and social services and support.

Social capital can be said to have complex effects. Pekka Ruuskanen (2003) divided the benefits of social capital into direct and indirect benefits. Among the indirect benefits he mentions the facilitation of joint action, social support and coordination of social functions. Direct benefits are the immediate gratification brought by confidence and successful communication. The aim of social capital is to increase people's wellbeing, so that the motivation for measuring social capital, at its finest, lies in how to increase wellbeing even-handedly. Communities or societies are not united by inequality. Mark Woolcock $(2000,28)$ has criticised the idea of social capital for encouraging economic imperialism. Jouko Kajanoja $(2002,181)$, on the other hand, argues that if economic growth arouses concern in society, then it becomes necessary to consider what is actually understood by the economy and economic policy. The economy can be analysed from the standpoint of its aims and not merely as pure efficiency.

Social capital is generally regarded as a positive resource, which it undoubtedly is. However attention has also been drawn to the possible use of social capital for the purposes of alienating certain groups. Alejandro Portes and Patricia Landolt (1996) adduce an example of such behaviour in working life. Reciprocal trust and social relations between members of ethnic groups can lead to ethnic groups offering jobs only to their own members and leaving others out. In that case the social capital of minority groups leads to increasing segregation of labour markets (see Forsander 2002, 60). Correspondingly, if the majority population fails to genuinely accept different ethnic groups in different areas of society, immigrants' sense of marginalisation is increased and the positive social capital potentially generated in reciprocal interaction fails to develop. 
It is probable that the factors involved in social capital - trust, social networks and participation - are significant in the process of the integration of immigrants. Trust in the majority population, other immigrant communities and one's own ethnic group provides an instrument for creating a social network and for participating in society, and hence also for integration in society. In order for an individual, community or society to function, trust and confidence are necessary. Trust is thus linked with both formal organisations and the hidden structures of society, and with visible and invisible ways of acting. Trust is always bound up with a particular situation. The functioning of social networks, and sharing or participating in them, express how trust operates. The process is contextually-bound and vulnerable to conflict. In other words, trust is not only a resource, but also a risk. Inequality between people does not unify a community or society, so that social capital at its best can promote wellbeing and its socially just distribution.

In this study, the sources of social capital are defined as the individual, the community and society as a whole. Trust is the instrument of social capital, while social networks and participation function as resources for social capital. The benefit of social capital is the resultant wellbeing at the level of both individuals and communities and society. At its best the theory of social capital can make a contribution towards gaining an insight into the integration process of immigrants into society, and also the factors slowing down or hindering integration (alienation). It can also be asked, from a critical standpoint, what demonstrates that an immigrant has successfully integrated.

\section{Methods}

This study investigates the integration of immigrants from the perspectives of employment. The theoretical framework is provided by the theory of social capital. The research questions are as follows:

- what background information do immigrants have?

- how do immigrants find employment?

The empirical research material of this study is made up of thirty (30) interviews with immigrants, which were carried out in the cities of Turku (10) and Kuopio (10) and the town of Janakkala (10), and four interviews with officials and others dealing with immigrant affairs. Turku and Kuopio represent urban centres and Janakkala a rural district. The purpose of the interviews with officials of the Department of Employment and various project workers was to gain an overview of Finnish immigrant affairs in the various local communities. Further research material consisted of statistical data and personal observation. 
The interviews were carried out during the period 23.6.2004-28.1.2005. The contact information of the respondents was obtained by contacting so-called 'key informants' such as Employment Offices. Immigrants themselves also passed on contact information for their friends and acquaintances. The social network channel turned out to work well, because in this case confidence in the occurrence of the interview had already been formed. One immigrant refused to be interviewed for fear that the interview would compromise his chances of acquiring a Finnish residence permit. Two immigrants failed to turn up for an interview at the agreed time. The interviews were carried out by agreement either at the immigrant's home, in public areas, at workplaces, in Employment Offices or in multicultural centres. The interviewees themselves were able to choose the location.

The interviews were semi-structured thematic interviews, with the subject matter of the interviews planned in advance. The themes of the main body of the interview were divided into background information (age, gender, language skills, home country, education, employment), social network and participation (how the respondents had found employment in Finland, which factors helped with finding work, social relationships) and also trust and confidence (confidence in the future and in integration in Finland). The primary aim was to speak Finnish in the interviews, but that was not fully realised. Four interviews were carried out in English. The purpose of using Finnish was to eliminate inadequate Finnish language skills as a potential barrier to employment and integration. The interviews lasted from half an hour to more than three hours. Eleven interviewees refused to allow the interviews to be recorded, and in these cases manual notes were made during the interview.

The recorded material was transcribed for the sale of the analysis. The interviews were manually divided into passages related to the research questions. After the creation of a thematic card index, answers were categorised with the aim of finding similarities and exceptions.

Nineteen of the interviewees were females and eleven were males. The age distribution was from age 27 to age 59, with the average age of the males 36 years and the females 33 years. The interviewees represented twelve immigrant groups: Russian (6), Turkish (4), Chinese (3), Estonian (3), Iranian (3) Thai (3), Moroccan (2), Iraqi (2), Eritrean (1), Tadžik (1), Italian (1) and Ethiopian (1). In the data, the immigrants have been classified as employed, unemployed, students and others. 'Others' here means those doing housework. The limited amount of material and its division into data from a variety of national groups imposed ethical restrictions which prevented the analysis of the data by nationality. 


\section{Results}

\section{Selected background information about the immigrants}

Almost all those interviewed (84\%) had moved from their home country to Finland voluntarily. The main reasons for coming to Finland were marriage or relationship with a Finn, work assignments from a multinational employer (in which case the assignment in Finland was one phase in the individual's career path), and desire for adventure. Women stated that their main reason was marriage to a Finnish man, whereas men's reasons for migrating were distributed more evenly between the different options. In this data, at least, study in Finland was rarely given as the main reason for moving.

The desire for adventure as a reason for migration is interesting. When the interviewees spoke of their desire for adventure, they stated that it was interesting to see and get to know different people and cultures. In such cases, there were not necessarily any long-term plans to stay in Finland or any interest in learning Finnish. If Finland failed to come up to expectations, they would move on to the next interesting country. The attitudes of such 'global wanderers' to moving and living abroad were flexible. Only men gave 'desire for adventure' as a reason for moving, a fact which may reflect cultural and gender differences. Women spoke of marriage and starting a family with a Finnish man. This was the case even when the relationship had lasted a comparatively short time, and knowledge of Finland was still quite limited. Besides trust, migration demanded of the women courage and even a desire for adventure.

There was much discussion over Finnish language skills or their absence. All the respondents thought that it was difficult to speak and write Finnish. If they were fluent speakers, they were not necessarily able to read and write Finnish. Learning a foreign language is naturally exceptionally difficult when the immigrant has had no opportunity in their home country to become literate in their own native language. As far as the immigrants who wished to stay in Finland were concerned (68\%), there was no questioning their desire to learn Finnish. Where and how to learn the language most effectively was more problematic. It was felt that the courses directed towards immigrants were too short and too heterogeneous in level. If the immigrant was not participating in working life, there were few forums in which the language could be practiced. Housewives and the unemployed felt that they were in a difficult situation, because in the opinion of immigrants Finns do not normally talk to strangers, for example, at bus-stops, in buses, or in shops. Children can provide a slight chance of contact with other adults, because through their own children the parents can get to know the parents of other children. 
Every respondent (30) had work experience in their home country of periods ranging from several months to decades. In addition, the great majority (95\%) had received some degree of education in their home country. If the immigrant had Finnish language skills and possessed a professional or vocational qualification from their home country or a Finnish qualification, he or she had most probably found employment. The interviewees felt that training in Finland was important because Finnish employers value Finnish education and training in particular. Furthermore, it was the experience of all such interviewees that their language skills had improved during their training, which facilitated not only gaining employment, but also making friendships with Finns. However, there was dissatisfaction with the numerous courses which did not genuinely lead to employment.

Of those who had resided in Finland for more than five years, $73 \%$ of the women and $82 \%$ of the men were employed. In the light of the data from this study, gaining employment is to some extent harder for women than for men, but an alarming number of those who had lived in Finland for less than five years were out of work. $65 \%$ of such women and $71 \%$ of such men were unemployed, or in other words, only one in three had found work. There was a clear connection between length of residence and finding employment. 36\% (of all respondents) were employed in the hotel and restaurant trade, and one in four (24\%) in service sector work. $5 \%$ of those in the hotel and restaurant business had set up their own business.

\section{Immigrants' paths to employment in Finland}

The interviewees were asked how they had found out about job vacancies. One in three reported that they had first received information about vacancies from the Employment Office, and one in five by approaching the employer directly asking for work. One in seven had found out about jobs through friends. In this data, official channels represented the primary source of information about jobs.

Employment Office officials had assisted the immigrants to find courses, places on training programmes and work experience placements, and immigrants were very satisfied with this service. However, the more qualifications the immigrant had, the more critical he or she was about the quality of these services. Work experience placements had great significance for both those with vocational or professional training and those without. In the best case, a successful period of work experience led directly to long-term employment and further training. The general desire was for an increase in the number of internships or work experience placements available. Learning at work and apprenticeships were especially wished for by those immigrants who had little basic education behind them. 
- Interviewer: How did you acquire the information about the job opening?

- Interviewee: The Employment Office is good. You can get information about courses, jobs and everything, what papers must be filled. But there it ends. The officials should telephone to the employers and recommend that the person be hired, say it is worth it. Speak on our behalf. It would help. No, on the contrary, here is the phone number, phone and pay a visit. Personal contact is important, I understand, but before the contact they should phone and speak on our behalf. Who will then help when one does not know anybody who can tell that this person is worth hiring? (A 47-year-old woman, Kuopio.)

The respondents were surprised by the role of the Finnish system in obtaining work. Officials primarily limited themselves to passing on information about a vacancy. Immigrants wanted officials to speak to employers about the immigrant's skills and strengths and why he or she would be worth employing. This issue arose particularly in the answers of those immigrants who had no Finnish spouse and hardly any social relationships with Finns.

Information about a vacancy does not necessarily lead to being given the job. Of all the immigrants interviewed, $57 \%$ had found work for different periods with the help of friends and acquaintances. By and large these jobs were temporary. The role of social relationships in obtaining employment is particularly important for finding the first, usually temporary, paid employment. After that the immigrants felt that they could themselves have an influence on the employment process. If work was done well, a good reputation would spread around. After initial success on the labour market, it also became easier to approach other employers directly.

- Interviewer: When you got the job, what factors influenced it?

- Interviewee: Yes, the big plus was to have a Finnish friend to recommend me to the employer. Even though it was seasonal work, it helped. The latter employer telephoned my former employer and heard that I was liked. With own work, confidence has to be obtained. I say that there is no significance which country you come from. The main thing is that the personalities click. And personal contact is the best. I took my papers there, and I phoned back. I was active and I got the job. (A 45-year-old woman, Janakkala).

Work communities in which immigrants had been employed received both praise and blame from the respondents. How the working community received the immigrant was greatly affected by why the immigrant had been hired. Was it for humanitarian reasons or to get the job done? If purely humanitarian reasons were involved, the working tasks 
were likely to be artificial. In the opinion of the immigrants, if the employer and work community had a genuine desire to see the immigrant worker as a potential resource for the work community, and genuine faith in him or her, the tasks were not artificial, which in turn ensured equal treatment for all the workers.

Those immigrants who were self-employed preferred to hire other immigrants. Reasons given for this included the inability of Finns to serve customers properly and the way Finns carefully guard demarcation lines in working life.

- Interviewer: You own a company, what kind of workers do you hire?

- Interviewee: Usually foreigners. They are used to doing all kinds of work, cleaning, serving and preparing food. The Finns say, "I am a cook, I do not clean". Or "I am a waiter, I cannot prepare food". The foreigners know this work better. Some of them say, yes, they can do the chores, but they cannot. When there are a lot of customers, one must be quick. Our attitude is to be quick; the customer does not want to wait for long. It is service. (A 36-year-old male entrepreneur, Turku.)

All those interviewed desired to participate in working life, and only the housewives pictured involvement in working life outside the home as a matter for the future. Factors behind the desire to participate in work were, understandably enough, the hope for a better income and the hope of forming new social relationships. Some of the women with unemployed husbands had turned down work that had been offered. The unemployed husband and father no longer had the same role of responsibility for the family income as in the home country. Although the family respected the will of the father in family matters, his position and authority in the family had been shaken or at least altered. If the mother of the family found work or obtained a place to study, it was difficult for her as a wife and mother to take up these offers in view of the family's culture. Independence of the wife (work outside the home) or efforts towards independence (education) were felt to threaten in some measure the balance of the family.

\section{Summary and discussion}

The commonest reasons for moving to Finland given in this research material were family reasons: marriage to or a relationship with a Finn. The next most commonly expressed reasons for moving were job opportunities offered by multinational companies, desire for adventure, 'return migration' of persons of Finnish ancestry, and exile or asylum-seeking. No interviewee mentioned hope of economic or social improvement among their reasons for moving. 
Participation in paid work defines the individual's membership of Finnish society. The unemployed, whether immigrants or members of the majority population, experience a sense of alienation from society. Work has its own instrumental value, but also provides evidence of social validity (Vähätalo 1998; Kortteinen and Tuomikoski 1998). It is harder for immigrants to find employment than for the majority population. Unemployment affects the wellbeing of immigrants and their families, as is also the case with the majority population.

As yet, the Finnish labour market has not divided into work for immigrants / certain social groups and work for the majority population. In this study, however, the service sector employed most immigrants, so that sectorisation of the labour market could be said to have taken place, but on the other hand the service sector is also a significant employer of the original population. Some of the immigrants felt that they had not found work in Finland matching their qualifications. Entrepreneurship in this data played an insignificant role, if the data are considered as a whole. The only entrepreneurs were working in the hotel and restaurant sector. It is worth recalling that in Finland, immigrants' businesses are located in areas with relatively large immigrant population.

The demands of Finnish working life are rigorous: the ability to work independently must be combined with being a competent 'team player'. Social skills have significance for anchoring the individual both in the work community and more broadly in Finnish society as a whole. Active and courageous individuals who wanted to learn something new and wanted to learn the language were most likely to find good employment. Although certain problems in reconciling customs and habits remained, such difficulties were not insurmountable. But if the individual was inactive, finding employment was always difficult and sometimes impossible. This situation is familiar from the Finnish debate on alienation. Those persons who have not acquired skills, or have a tendency to withdraw, easily become alienated from society.

The combined effect of various factors was discernible in the integration of the immigrants. An immigrant's integration was influenced by the reason for migrating, attitudes, normative factors and the labour market situation. Human capital, in the form of the individuals' skills and knowledge, and attitude and personality factors affect the resources for life at the immigrant's disposal. Immigrants described themselves as energetic and active. The reason for migration influenced integration: had the individual been forced to decide to move (asylum-seekers, refugees) or had the decision been voluntary (family reasons, work, study, desire for adventure)? The integration process was retarded by lack of language skills, unemployment and scarcity or absence of social contacts. This result is congruent with the study of Annika Forsander, which was published in the year 2002 . 
Social capital requires cooperation and interaction. Factors contributing to the generation of the social capital and with it the wellbeing of the immigrants were human capital (e.g. the individual's attitudes and skills), the receptiveness of the community, the community's social networks and relationships, and the general social and political situation (e.g. legislation and policies). The creation of trust and functional interaction facilitated activity together.

Social capital (trust, social networks and participation) had an effect on the immigrants' information channels, i.e. on what, how and from whom immigrants received information about jobs, social security and general social matters. The openness and mutual trust of communities provided the opportunity to participate in both working life and residential communities and also in parental responsibilities. Interaction is the prerequisite for the creation of social relationships and the formation of social capital. Sparse contacts with the original population are a risk. The mechanisms of alienation and exclusion appear as negative attitudes and prejudices. In areas of high unemployment in Finland, immigrants are considered a threat to the employment of Finns.

In general it was agreed (92\%) that it was easy for most Europeans to live in Finland. Russians and immigrants from developing or third world countries were treated with most reserve in Finland, according to $47 \%$ of the immigrants interviewed. The quality of interaction, or what kind of feelings remained after contact with a Finn, was vital for a sense of acceptance. The suspicions and strong prejudices of the majority population about what all immigrants are like caused immigrants disappointment and annoyance. All unfair treatment or poor service was not necessarily racial discrimination, even when it could easily be connected with ethnic origin. Not all minorities feel an automatic sense of solidarity with each other. Sympathy is selective.

In speaking of integration, it is important to remember the challenge of the integration of members of the same family of different ages (working-age men and women, young people, children and the elderly). The aim of integration is to achieve a good life, so that the same ingredients constitute wellbeing for immigrants as for the original population: income, finding a place, human relationships and health. When these elements have been attained, immigrants will become members of the local community who are satisfied with their lives. 


\section{References}

Allport, Gordon W. 1954. The Nature of Prejudice. Reading, Mass.: Addison-Wesley Publishing Company.

Bourdieu, Pierre. 1979. Distinction. A Social Critique of the Judgment of Taste. London: Routledge \& Kegan Paul.

Bourdieu, Pierre. 1986. The Forms of Capital. In: Handbook of Theory and Research for the Sociology of Education, edited by J. Richardson. New York: Greenwood Press.

Castles, Stephen and Miller, Mark J. 1998. The Age of Migration: International Popular Movements in the Modern World. London: Macmillan Press.

Coleman, James S. 1988. Social Capital in the Creation of Human Capital. The American Journal of Sociology, vol. 94, Supplement: 95-120.

Ekholm, Elina. 1994. Syrjäytyä vai selviytyä - pakolaisten elämää Suomessa. Sosiaali- ja terveysministeriön selvityksiä 1994: 9. Helsinki.

Forsander, Annika. 2001. Työvoiman tarve ja maahanmuuttopolitiikka - Millä ehdoin maahanmuuttajien osaaminen on vastaus työvoiman kysyntään? In: Aukeavat ovet - kulttuurien moninaisuus Suomen elinkeinoelämässä, edited by Marja- Liisa Trux, pp. 144-193, Helsinki: WSOY.

Forsander, Annika. 2002. Luottamuksen ehdot. Maahanmuuttajat 1990-luvun suomalaisilla työmarkkinoilla. Väestöliiton Väestöntutkimuslaitoksen julkaisusarja D 39/2002. Helsinki.

Forsander, Annika and Ekholm, Elina. 2001. Etniset ryhmät Suomessa. In: Monietnisyys, yhteiskunta ja työ, edited by Annika Forsander, Elina Ekholm, Petri Hautaniemi, pp. 83-113, Helsinki: Palmenia-kustannus.

Green, Geoff, Mike Grimsley, Ann Suokas, Margaret Prescott, Tony Jowitt and Rachel Linacre. 2000. Social Capital, Health and Economy in South Yorkshire Coalfield Communities. Sheffield: Sheffield Hallam University.

Hammar, Thomas. 1990. Democracy and Nation State. Aliens, Denizens and Citizens in a World of International Migration. Aldershot: Avebury.

Hyyppä, Markku T. 2002. Elinvoimaa yhteisöstä. Sosiaalinen pääoma ja terveys. Keuruu: PS-kustannus.

Ilmonen, Kaj. 2002. Luottamus paikallisiin instituutioihin ja sosiaalisiin verkostoihin. In: Sosiaalinen pääoma ja hyvinvointi. Näkökulmia sosiaali- ja terveysaloille, edited by Pekka Ruuskanen, pp. 36-159, Jyväskylä: PS-kustannus.

Kajanoja, Jouko, Simpura, Jussi. 2002. Sosiaalisen pääoman lupaukset. In: Tutkimus ja talouspolitiikkakirjoituksia taloudellisesta kasvusta, edited by Jouko Kajanoja, Jaakko Kiander, Iikko B. Voipio, pp. 161-181. Helsinki: Valtion taloudellinen tutkimuskeskus.

Kortteinen, Matti and Tuomikoski, Hannu. 1998. Työtön. Tutkimus pitkäaikaistyöttömien selviytymisestä. Helsinki: Tammi.

Kotouttamislaki 493/1999.

Kotouttamislaki 2006.

Lange, Anders and Charles Westin. 1981. Etnisk diskriminering och social identitet. Stockholm: LiberFörlag, Publica.

Maahanmuuttajien elinolot. Venäläisten, virolaisten, somalialaisten ja vietnamilaisten elämää Suomessa 2002. Elinolot 2003:1. Helsinki: Tilastokeskus.

Niemelä, Pauli. 2004. Sosiaalinen pääoma Suomen kunnissa. Kunnallisalan kehittämissäätiö. Vammala.

Pehkonen, Aini. 2005. Kylä kutsuu... Tutkimus tulomuuttoprosesseista maaseudulle. Siirtolaisuusinstituutin tutkimuksia A 22. Helsinki: Helsingin yliopistopaino. 
Pehkonen, Aini. 2006. Maahanmuuttajan kotikunta. Kunnallisalan kehittämissäätiö. Vammala: Vammalan kirjapaino.

Portes, Alejandro and Patricia Landolt. 1996. The Downside of Social Capital. The American Prospect no. 26, May-June 1996.

Pulkkinen, Lea. 2002. Mukavaa yhdessä: sosiaalinen alkupääoma ja lapsen sosiaalinen kehitys. Jyväskylä: PS-kustannus.

Putnam, Robert D. 1993. Making Democracy Work. Civic Traditions in Modern Italy. New Jersey: Princeton University Press.

Putnam, Robert D. 1995. Bowling Alone: America's Declining Social Capital. Journal of Democracy, Vol.6 (1995) 1, 64-78.

Putnam, Robert D. 2000. Bowling Alone. The Collapse and Revival of American Community. New York: Simon \& Schuster.

Rath, Jan. 2000. Introduction: Immigrant Businesses and their Economic, Politico-Institutional and Social Environment. London: Macmillan Press Ltd.

Ruuskanen, Pekka. 2001. Sosiaalinen pääoma - käsitteet, suuntaukset ja mekanismit. VATTtutkimuksia 81. Helsinki: Valtion taloudellinen tutkimuskeskus.

Ruuskanen, Pekka. 2003. Verkostotalous ja luottamus. Jyväskylän yliopisto. SoPhi.

Siisiäinen, Martti. 2003. Yksi käsite, kaksi lähestymistapaa: Putnamin ja Bourdieun sosiaalinen pääoma. Sosiologia 3, nro 2003: 204-218. Westermarck-seuran julkaisuja.

Simpura, Jussi. 2002. Sosiaalista pääomaa mittaamassa. In: Sosiaalinen pääoma ja hyvinvointi. Näkökulmia sosiaali- ja terveysaloille, edited by Petri Ruuskanen, pp. 200-222. Keuruu: PS-kustannus.

Sinkkonen-Tolppi, Merja. 2005. Maailma kutsuu, katkeavatko juuret? Nuorten kotiseudulle kiinnittyminen ja sen yhteys nuorten sosiaaliseen pääomaan. Kuopion yliopiston julkaisuja E. Yhteiskuntatieteet 125. Kuopio: Kuopion yliopisto

Spellerberg, Anne. 1997. Towards a Framework for the Measurement of Social Capital. In: Social Capital and Policy Development, edited by David Robinson. Wellington: Institute of Policy Studies.

Stalker, Peter. 2000. Workers without Frontiers. The Impact of Globalisation on International Migration. London: Lynne Rienner Publisher.

Stenberg, E. 2004. Asenteet maahanmuuttoa kohtaan uusiksi. Helsingin Sanomat 8.7.2004, A5. Mielipidesivu.

Statistical Yearbook of Finland 2004. Helsinki: Statistics Finland.

Sztompka, Piotr. 1999. Trust. A Sociological Theory. Cambridge: Cambridge University Press.

Ulkomaalaislaki 2004.

Vähätalo, Kari. 1998. Työttömyys ja suomalainen yhteiskunta. Helsinki: Gaudeamus.

Woolcock, Mark. 2000. Sosiaalinen pääoma, menneisyys, nykyisyys, tulevaisuus. In: Sosiaalinen pääoma: globaaleja ja paikallisia näkökulmia, edited by Jouko Kajanoja and Jussi Simpura, pp. 25-56. Raportteja 252. Helsinki: Stakes ja Valtion taloudellinen tutkimuskeskus.

Yhdenvertaisuuslaki 2004 (asetus numero 21).

Ylänkö, Maaria. 2000. Kansainvälistymisen kahdet kasvot - muuttoliikkeet ja kulttuurinen globalisaatio. In: Aukeavat ovet - kulttuurien moninaisuus Suomen elinkeinoelämässä, edited by Marja-Liisa Trux, pp. 21-84, Helsinki: WSOY. 